\title{
Fluorescein angiography findings in a case of Rubinstein-Taybi syndrome
}

This article was published in the following Dove Press journal:

Clinical Ophthalmology

2I August 2012

Number of times this article has been viewed

\author{
David J Jacobs' \\ Julia Sein'
}

Audina M Berrocal'

Alana L Grajewski ${ }^{1,2}$

Elizabeth Hodapp'

'Department of Ophthalmology, Bascom Palmer Eye Institute, University of Miami Miller School of Medicine, Miami, FL, ${ }^{2}$ Department of Ophthalmology, University of Minnesota, Minneapolis, MN, USA
Correspondence: David J Jacobs

Trinity Health Plaza 16, 28I5 16th

Street SW, Minot, ND 5870I, USA

Tel +I 70I 8523937

Fax + I 7018573129

Email jacobs.retina@gmail.com

\begin{abstract}
The purpose of this report is to describe the fluorescein angiography findings in a case of Rubinstein-Taybi syndrome. Fundus photography and fluorescein angiography were performed on a 6-year-old male with Rubinstein-Taybi syndrome due to CREB binding protein gene mutation. Fundus photography showed glaucomatous cupping and diffusely attenuated retinal vasculature. Choroidal vasculature was prominent due to diffuse retinal atrophy with scattered focal retinal pigment epithelial changes. Fluorescein angiography showed retinal vascular attenuation, prolonged arteriovenous transit time with delayed venous filling, late small vessel leakage, and 360 degrees of peripheral avascularity. Peripheral retinal avascularity and retinal vascular inflammation evidenced by late small vessel leakage can be demonstrated by fluorescein angiography in the retinal dystrophy of Rubinstein-Taybi syndrome.
\end{abstract}

Keywords: Rubinstein-Taybi syndrome, CREB binding protein, gene mutation

\section{Introduction}

Rubinstein-Taybi syndrome is a congenital malformation disorder characterized by short stature, mental retardation, microcephaly, broad great toe and thumb, and various facial abnormalities (hypoplastic maxilla, prominent beaked nose, low-set ears, antimongoloid palpebral fissures). ${ }^{1}$ First described in 1963 by Rubinstein and Taybi, this condition occurs in approximately one in 100,000 newborns. Most patients with Rubinstein-Taybi syndrome have a mutation of the CREB binding protein gene which codes for a regulatory protein in fetal development. ${ }^{2}$ Most cases are isolated, but parental autosomal dominant transmission can be seen. ${ }^{3}$ Various ocular abnormalities linked with this syndrome (84\%) include glaucoma, down-slanting palpebral fissures, epicanthus, strabismus, cataract, refractive error, colobomata, highly arched eyebrows, nasolacrimal duct obstruction, and anterior segment dysgenesis. ${ }^{1,4}$ Van Genderen et al found a high frequency of electroretinographic abnormalities in 14 of 18 patients (78\%), eight with decreased cone responses and six with decreased cone and rod responses. Similarly, 18 of 23 patients examined (78\%) showed mild to severe fundus abnormalities including absent macular reflexes, increased reddening of the foveal area, unusual distribution of pigmentation, lacquer cracks, and chorioretinal coloboma. ${ }^{1}$ While there are numerous publications on Rubinstein-Taybi syndrome, the literature on related ocular disturbances is limited. To our knowledge, there are no reports of fluorescein angiography evaluation of Rubinstein-Taybi syndrome. We report fluorescein angiography findings of vascular attenuation, prolonged arteriovenous transition time, delayed venous filling, small vessel leakage, and peripheral avascularity in a child with Rubinstein-Taybi syndrome. 


\section{Case report}

A 6-year-old male, born at 34 weeks' gestation with Rubinstein-Taybi syndrome due to CREB binding protein gene mutation underwent fluorescein angiography to characterize better his retinal vasculature attenuation. The patient had characteristic clinical features of Rubinstein-Taybi syndrome, including microcephaly, down-slanting palpebral fissures, broad thumbs and first toes (Figure 1), bicuspid aortic valve, and an ocular history of high myopia -6.00 diopters, exotropia, epiblepharon, and congenital glaucoma status post trabeculotomy OU and Baerveldt glaucoma implant OS. Visual acuity was fix and follow OU. Intraocular pressures were $21 \mathrm{mmHg}$ OD and $18 \mathrm{mmHg}$ OS. Anterior segment examination showed clear corneas OU, clear lens OD, small nasal cataract OS, superonasal tube OS, and posterior synechiae OS. Fundus examination showed sharp discs with significant glaucomatous cupping OU and optociliary shunt vessel OS.

Retinal vasculature was attenuated OU. Choroidal vasculature was prominent due to diffuse retinal atrophy with scattered focal retinal pigment epithelial changes OU (Figure 2). Fluorescein angiography showed retinal vascular attenuation, prolonged arteriovenous transition time with delayed venous filling OD (Figure 3), and late small vessel leakage nasally OS (Figure 4). A total of 360 degrees of peripheral avascularity was also evident OU (Figure 5). Vital signs, including heart rate, blood pressure, and oxygen saturations were within normal limits throughout the examination.

\section{Discussion}

The present case has many of the ocular findings commonly reported in Rubinstein-Taybi syndrome including

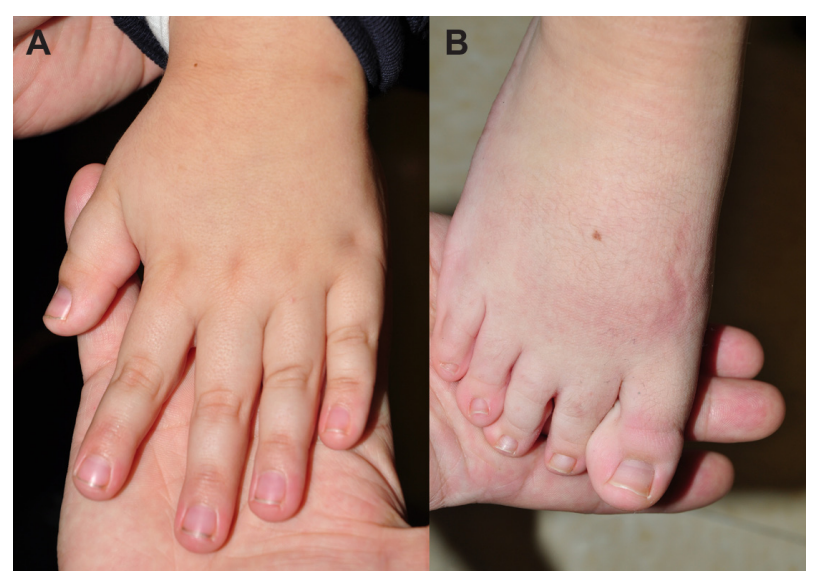

Figure I Photographs of $(\mathbf{A})$ thumb and $(\mathbf{B})$ toe.

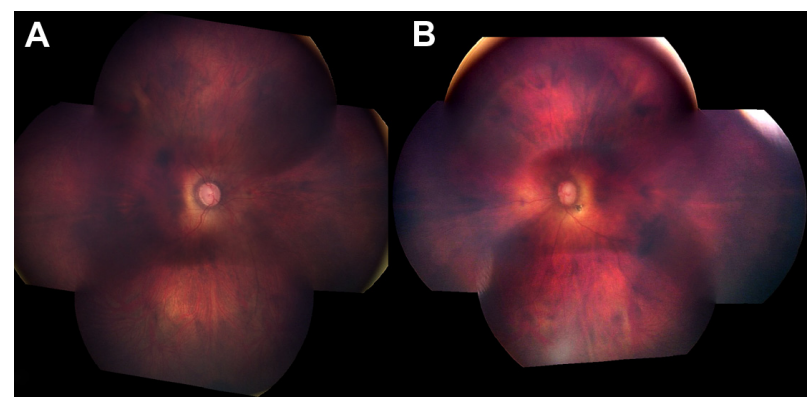

Figure 2 Fundus photographs of (A) right eye and (B) left eye.

down-slanting palpebral fissures, glaucoma, high myopia, strabismus, and retinal dystrophy. ${ }^{5,6}$ The fluorescein angiography findings of Rubinstein-Taybi syndrome identified in this case include vascular attenuation, prolonged arteriovenous transition time with delayed venous filling, small vessel leakage, and peripheral avascularity. Vascular attenuation is not a surprising finding because it is common to retinal dystrophies. Prolonged transit time has been identified in glaucoma, but the marked delay in this case is unexpected because intraocular pressures were controlled. ${ }^{7}$ Prolonged transit time can also occur in chorioretinal inflammatory disorders. ${ }^{8}$ An inflammatory process may have contributed to the prolonged transit time in this case. The late small vessel leakage showed that retinal vascular inflammation was present, and recent Baerveldt glaucoma implant surgery may have been a contributing factor. Peripheral avascularity, common in retinopathy of prematurity, familial exudative vitreoretinopathy, and incontinentia pigmenti, has not been described previously in Rubinstein-Taybi syndrome. The degree of peripheral avascularity in the

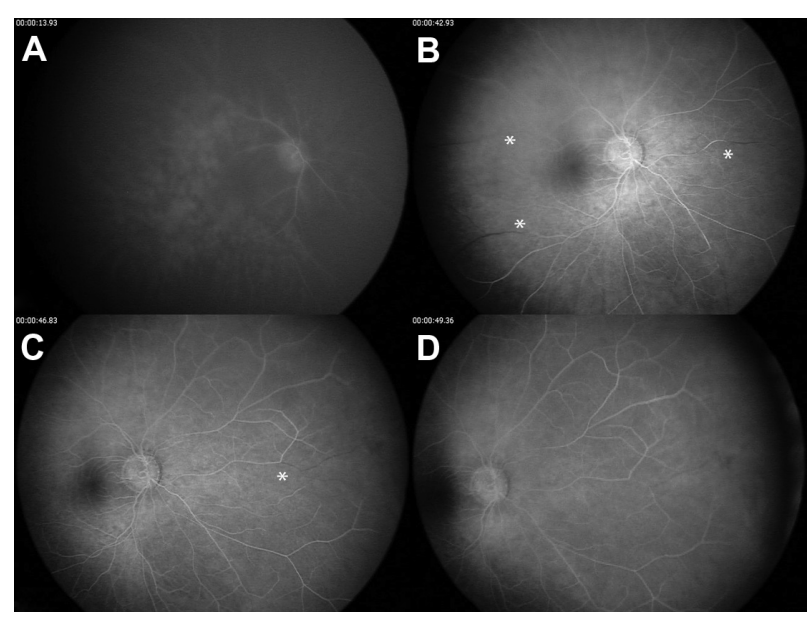

Figure 3 Arteriovenous transit phase fluorescein angiography of right eye. (A) Arterial filling at 19 seconds. (B and C) Mid-venous phase at 42 and 46 seconds (asterisks identify areas of delayed venous filling). (D) Venous filling not complete until 49 seconds. 


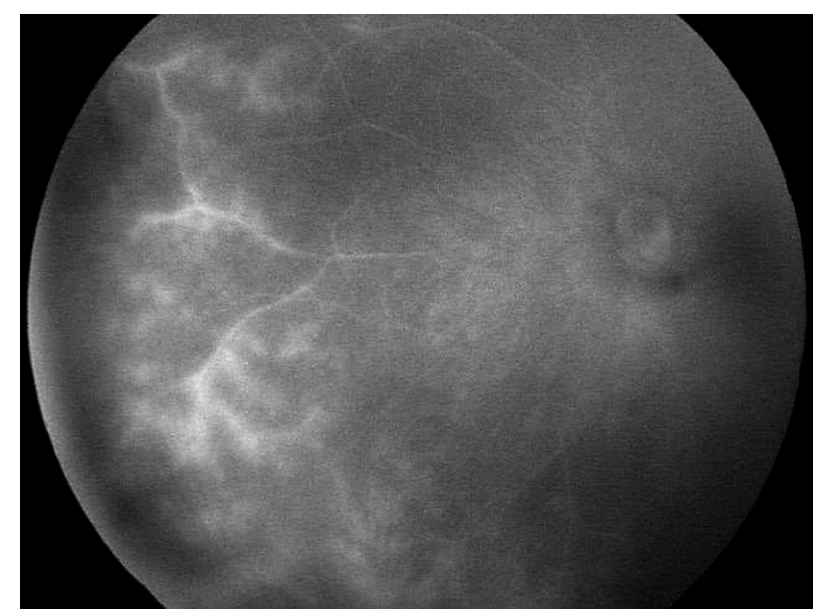

Figure 4 Late nasal small vessel leakage OS.

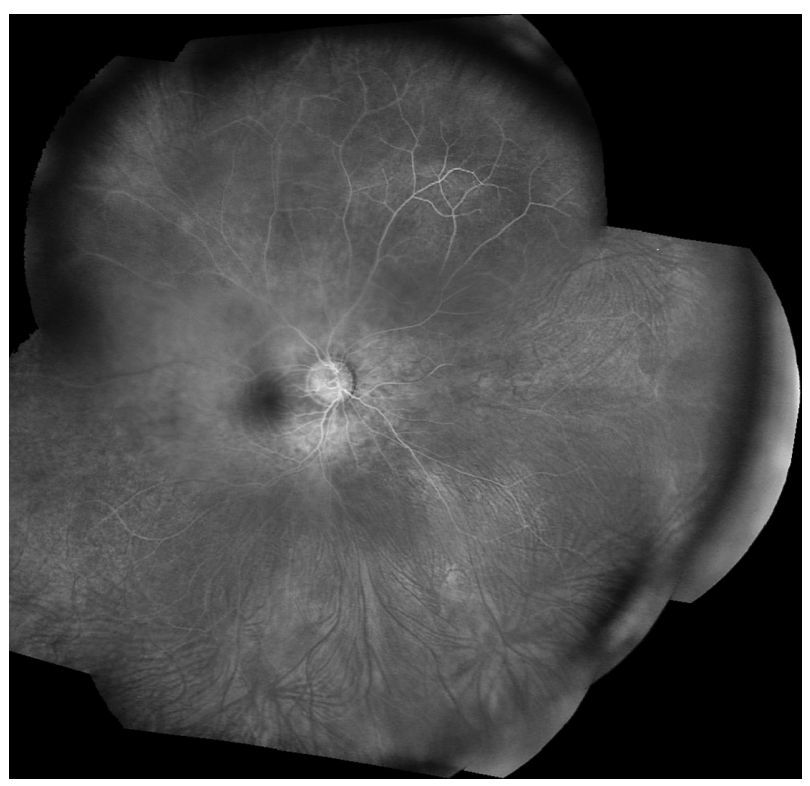

Figure 5 Montage fundus photograph showing peripheral avascularity. present case is not typical for a birth history of 34 weeks' gestational age. Mutation of the CREB binding protein responsible for growth retardation and other skeletal and cardiac abnormalities in Rubinstein-Taybi syndrome may also affect vascularization of the retinal periphery. Further investigation with fluorescein angiography is warranted to characterize better the retinal vascular abnormalities of Rubinstein-Taybi syndrome.

\section{Disclosure}

The authors report no conflicts of interest in this work.

\section{References}

1. Van Genderen MM, Kinds GF, Riemslag FC, Hennekam RC. Ocular features in Rubinstein-Taybi syndrome: investigation of 24 patients and review of the literature. Br J Ophthalmol. 2000;84(10):1177-1184.

2. Roelfsema JH, Peters DJ. Rubinstein-Taybi syndrome: clinical and molecular overview. Expert Rev Mol Med. 2007;9(23):1-16.

3. Marion RW, Garcia DM, Karasik JB. Apparent dominant transmission of the Rubinstein-Taybi syndrome. Am J Med Genet. 1993;46(3): 284-287.

4. Rao SK, Fan DSP, Pang CP, et al. Bilateral congenital corneal keloids and anterior segment mesenchymal dysgenesis in a case of RubensteinTaybi syndrome. Cornea. 2002;21(1):126-130.

5. Roy FH, Summitt RL, Hiatt RL, et al. Ocular manifestations of the Rubinstein-Taybi syndrome. Arch Ophthalmol. 1968;79(3):272-278.

6. Quaranta L, Quaranta CA. Congenital glaucoma associated with RubinsteinTaybi syndrome. Acta Ophthalmol Scand. 1998;76(1):112-113.

7. Wolf S, Arend O, Haase A, et al. Retinal hemodynamics in patients with chronic open angle glaucoma. Ger J Ophthalmol. 1995;4(5):279-282.

8. Gass JDM. Vitiliginous chorioretinitis. Arch Ophthalmol. 1981;99(10): 1778-1787.
Clinical Ophthalmology

\section{Publish your work in this journal}

Clinical Ophthalmology is an international, peer-reviewed journal covering all subspecialties within ophthalmology. Key topics include: Optometry; Visual science; Pharmacology and drug therapy in eye diseases; Basic Sciences; Primary and Secondary eye care; Patien Safety and Quality of Care Improvements. This journal is indexed on

Submit your manuscript here: http://www.dovepress.com/clinical-ophthalmology-journal

\section{Dovepress}

PubMed Central and CAS, and is the official journal of The Society of Clinical Ophthalmology (SCO). The manuscript management system is completely online and includes a very quick and fair peer-review system, which is all easy to use. Visit http://www.dovepress.com/ testimonials.php to read real quotes from published authors. 